\title{
PEMBELAJARAN LAGU ORAY BUNGKA DALAM PEMBENTUKAN KARAKTER ANAK USIA DINI
}

\author{
Oleh: \\ Denden Setiaji, M. Pd \\ Universitas Muhamadiyah Tasikmalaya \\ denden@umtas.ac.id
}

\begin{abstract}
Abstrak
Kakawihan barudak yakni salah satunya kawih oray bungka sebgai salah satu media pembelajaran lagu-lagu tradisional Sunda khususnya kini mulai mengalami kemunduran bahkan nyaris dilupakan keberadaannya. Masuknya budaya-budaya barat yang sifatnya lebih popular disinyalir sebagai salah satu pengaruh terbesar menghilangnya kecintaan atau penghargaan terhadap sebuah karya-karya kawih atau kaulinan barudak. Permasalahan-permasalahan yang timbul menggerakan hati para seniman sunda salah satunya Mang Koko yang akhirnya membuat terobosan dalam lagu-lagu kakawihan barudak yang dikemas secara lebih mendalam. Karya yang dibawakan maupun notasinotasi yang terkandung di dalam karyanya secara tidak langsung dapat mengolah nilainilai pendidikan untuk pembentukan karakter anak sejak usia dini.
\end{abstract}

Kata kunci: Kawih Barudak; Oray Bungka

\begin{abstract}
Kawih is a Sundanese song that is not bound by special rules. Kakawihan is a Sundanese song used on traditional children's games. Kakawihan barudak one of them is titled oray bungka is one of the learning media of traditional Sundanese songs that began to decline even almost forgotten. The introduction of a popular western culture is the greatest influence of the disappearance of love or respect for the work of kakawihan barudak. A Sundanese artist that is Mang Koko moved to make a new breakthrough in packing the song kakawihan barudak. The work played and the notations contained in it can indirectly cultivate the value of education for the formation of the character of early childhood.
\end{abstract}

Keywords: Kawih Barudak; Oray Bungka. 


\section{Pendahuluan}

Provisi Jawa Barat merupakan provinsi yang memiliki keberagaman suku dan keberagaman seni budaya, khususnya di Jawa Barat terdapat beberapa jenis kesenian tradisional yang menjadi ciri atau kekhasan dari daerahnya masing-masing. Seiring dengan pesatnya perkembangan sains dan IPTEK serta pengaruh-pengaruh budaya barat yang semakin meraja di negeri sendiri, hal tersebut berdampak besar bagi berkembanagnya rasa sosialitas masyarakat kita yang dulunya berbudaya sedikit demi sedikit berubah menjadi radikal. Kecintaan akan tanah air dan bangsanya pun sudah mulai tergerus arus modernisasi yang sedang berlangsung hingga saat ini.

Tidak hanya demikian, globalisasi modern ini juga mengakibatkan berkurangnya pelestarian seni dan budaya yang ada di negeri ini. Khususnya di Jawa Barat, kecintaan masyarakan terhadap nilai-nilai budaya dan seni yang terdapat di daerahnya sudah mulai berkurang karena gencarnya pengaruh- pengaruh seni dan budaya barat yang tak terbendung dan menyebabkan masyarakat cenderung lebih menyukai hal tersebut karena faktor-faktor image yang tertanam dalam setiap individu bahwasanya jika tidak mengikuti perkembangan budaya masa kini maka akan disebut sebagai individu yang ketinggalan zaman.

Faktor yang mengakibatkan menurunya peranan seni dan budaya tradisional diantaranya ialah erosi budaya yang disebabkan masuknya budaya-budaya asing yang masuk di negara kita. Banyak kesenian asing yang menggeser seni trasidional kita ke lubang kubur. Tambahan pula daerah Jawa Barat adalah daerah yang sangat terbuka untuk menerima jenis-jenis kesenian yang masuk dari luar. Pada dasarnya karena Jawa Barat merupakan tempat lalu-lalangnya kesenian-kesenian luar sehingga untuk membendung erosi budaya sangat sulit dilakukan (Soepandi 1985:3).

Dari pemaparan diatas, maka jelaslah suatu hal yang sulit untuk membendung atau menahan gencarnya arus-arus modernisasi yang terus menerus masuk dan berkembang sehingga Jawa Barat pun seakan kehilangan sebuah jati diri yang sesungguhnya. Hal tersebut juga disebabkan produk-produk seni yang dihasilkan para seniman kurang memenuhi keinginan masyarakat, para senimannya pun lebih sibuk mengurus kepentingan individu yang mungkin tidak bisa dielakan lagi.

Jawa Barat merupakan daerah sangat kaya akan nilai-nilai kesenian dan budaya khususnya daerah tatar Priangan atau Sunda. Sunda merupakan daerah yang memiliki 
kekayaan budaya yang cukup beragam khususnya dalam bidang karawitan sekar. Karawitan sekar berasal dari kata karawitan vokal yang biasa di Sunda sendiri lebih dikenal dengan nama karawitan sekar. Karawitan sekar ini adalah sebuah seni suara yang subtstansinya menggunakan suara manusia.

Menurut Warnika yang dimaksud dengan karawitan vokal atau lebih dikenal dalam karawitan Sunda dengan istilah Sekar ialah seni suara yang dalam substansi dasarnya mempergunakan suara manusia. Tentu saja dalam penampilannya akan berbeda dengan bicara biasa yang juga mempergunakan suara manusia. Sekar merupakan pengolahan yang khusus untuk menimbulkan rasa seni yang sangat erat berhubungan langsung dengan indra pendengaran. Dia sangat erat bersentuhan dengan nada, bunyi atau alat-alat pendukung lainnya yang selalu akrab berdampingan. Fungsi dari karawitan sekar itu sendiri memiliki keberagaman fungsi, dintaranya sebagai sarana upacara adat atau religius hingga sebagai media hiburan.

Pada kehidupan orang Sunda pada masa lalu sejak mereka lahir secara tidak langsung telah didekatkan dengan alunan sekar. Sejak mereka lahir sang ibu menimang, meninabobokan dengan menggunakan sekar. Dalam mengajak bermain, dalam tahap-tahap mulai belajar bicara, belajar berjalan, sekar sangat sering didengarkan oleh orang tua atau pengasuhnya. Itulah sebabnya lagu-lagu dalam meninabobokan atau ngayun ngambing anak selalu populer dari masa ke masa, dalam arti kelestariannya terlihat karena selalu dilakukan dari generasi ke generasi.

Karawitan sekar di Sunda, memiliki berbagai kategori di dalamnya diantaranya ada kawih, tembang, dan kepesindenan. Ketiganya menjadikan karakter yang khas dari masing masing sebuah kesenian, berlandaskan permasalahan sebelumnya, kali ini penelitian difokuskan pada lagu-lagu yang dikategorikan dalam karawitan sekar kawih.

Kawih merupakan sebuah nyanyian yang diikat oleh ketukan atau birama sebagai mana diungkap RMA Koesoemadinata dalam Soepandi 1985:14 bahwa: Istilah kawih yang kemudian disusul dengan istilah tembang mempunyai pengertian yang sama.

Sekar tembang = kawih, ieu aya dua rupi:

1. Sekar irama merika: nya eta panjang atawa pondokna sora sareng wirahma sakarep-karep numutkeun raosna priaga, numbutkeun kageunahan nu tembang kayaning : tembang buhun rancag, tembang buhun raehan, beluk, kakawen, suluk, tembang Cianjuran, kakawihan dongeng. 
2. Sekar tandak nyaeta sekar anu ajeg wiletana tegesna lolongkrang-lolongkrang antara wirahma wirahma sami sadayana.

Sekar tembang = kawih terdapat dua macam

1. sekar irama merdika: adalah tembang yang berharga nada dan berirama bebas menurut rasa si penampil, seperti tembang buhun rancag, tembang buhun raehan, beluk, kakawen, suluk, tembang Cianjuran, kakawihan dongeng.

2. Vokal berirama ajeg/tetap adalah tembang yang memiliki irama tetap jelasnya jarak irama antara satu dengan yang lain jelas jaraknya.

perbedaan kawih dengan tembang

kawih adalah sekar irama merdeka (monometraschematika)

tembang adalah sekar irama bebas terikat oleh aturan pupuh (pollymetrachematika)

pengertian kawih dalam penelitian ini adalah nyanyian

Dari pemaparan di atas maka dapat disimpulkan bahwa kawih memiliki perbedaan dengan tembang atau kepesindenan. Yang menjadi perbedaan adalah bentuk birama yang berbeda. Berangkat dari beberbagai fenomena yang terjadi dan dipaparkan sebelumnya, peneliti memfokuskan pada penelitian kawih barudak yang berarti nyanyian anak-anak. Hal ini dikarenakan anak-anak merupakan cikal bakal penerus bangsa yang akan menentukan kemana arah kebudayan di negara ini dan tugas peneliti adalah menanamkan kecintan terhadap karya-karya seni yang ada di negeri ini khususnya di Jawa Barat.

Kawih barudak merupakan sebuah jenis karawitan sekar yang substansinya adalah suara anak-anak. Kawih-kawih kawih barudak biasanya dinyanyikan oleh anak-anak dalam kehidupan sehari-hari mereka dan biasanya dibawakan ketika mereka sedang bermain dengan teman-teman sebaya. Pemaparan tentang kawih barudak ini juga diungkap oleh Sadkar dalam Soepandi 1985:15) bahwa: Kawih barudak artinya nyanyian anak-anak dan kawih adalah bahasa ikatan yang merupakan curahan rasa yang disajikan memerlukan lagu.

Dari pemaparan di atas tentulah saja kawih barudak menjadi hal yang sangat penting dalam setiap permainan yang dibawakan oleh anak-anak di Jawa Barat, dari nyanyian-nyanyian yang dibawakan secara tidak langsung memberikan pendidikan secara non formal kepada mereka baik itu tentang pengetahuan nada-nada, rasa birama, dan nilainilai kebersamaan. 
Untuk lebih memberikan pemahaman yang lebih jelas dan mengkerucut tentang penelitian kali ini, peneliti mengambil satu sampel karya yaitu lagu kawih barudak yang diciptakan oleh Mang Koko Koswara yang berjudul Oray Bungka. Lagu Oray Bungka ini merupakan kawih barudak yang sederhana ciptaan Mang Koko sehingga lagu ini sangat cocok untuk dipelajari anak-anak pada jenjang sekolah dasar (SD).

\section{Kawih}

Kawih merupakan sebuah nyanyian yang diikat oleh ketukan atau birama sebagai mana diungkap RMA Koesoemadinata dalam Soepandi 1985:14 bahwa Istilah kawih yang kemudian disusul dengan istilah tembang mempunyai pengertian yang sama.

Sekar tembang = kawih, iеu aya dua rupi:

1. sekar irama merika: nya eta panjang atawa pondokna sora sareng wirahma sakarep-karep numutkeun raosna priaga, numbutkeun kageunahan nu tembang kayaning : tembang buhun rancag, tembang buhun raehan, beluk, kakawen, suluk, tembang Cianjuran, kakawihan dongeng.

2. Sekar tandak nyaeta sekar anu ajeg wiletana tegesna lolongkrang-lolongkrang antara wirahma wirahma sami sadayana.

Sekar tembang = kawih, terdapat dua macam:

1. sekar irama merdika: adalah tembang yang berharga nada dan berirama bebas menurut rasa si penampil, seperti tembang buhun rancag, tembang buhun raehan, beluk, kakawen, suluk, tembang Cianjuran, kakawihan dongeng.

2. Vocal berirama ajeg/tetap adalah tembang yang memiliki irama tetap jelasnya jarak irama antara satu dengan yang lain jelas jaraknya.

Menurut Setiaji (2012), Kawih merupakan Karawitan Sekar yang dalam bentuk penyajiannya termasuk pada sekar yang sebagian besar karyanya terikat oleh tempo dalam wiletan tertentu atau biasa disebut sekar tandak. Tetapi tidak begitu saja, beberapa karyakarya kawih tertentu juga ada yang tidak terikat oleh ketukan atau bebas wirahma. Kawih biasa disajikan secara anggana sekar (solo) juga bisa disajikan dalam bentuk layeutan (paduan suara). Pola ornamentasi pada kawih biasanya lebih terikat pada notasi yang sudah ada. Sebagaimana diungkap oleh Warnika dalam (pangauban-sekar.blogspot.com) bahwa 'Pengertian kawih pada mulanya sama dengan kepesindenan, tetapi perkembangan memecah kedudukan yang berbeda antara kawih dan kepesindenan. Perbedaan itu bukan 
saja terletak pada pergelaran dan teknik-teknik bernyanyi saja, melainkan juga lingkungannya'.

Lagu-lagu kawih wanda anyar lebih banyak berorientasi pada lagu-lagu perkembangan (kreasi baru), sedangkan pada lagu kawih kepesindenan adalah lagu-lagu klasik dan tradisional. Memang yang paling menonjol sekarang pada kawih ialah segi perkembangan lagu-lagu barunya. Lagu-lagu itu lebih banyak bergerak pada lingkungan pendidikan dan kaum remaja tertentu. Hal-hal yang berhubungan dengan pendidikan, dimana lagu-lagu kawih banyak diciptakan oleh para juru sanggi (komponis) secara khusus untuk kebutuhan program pengajaran. Tokoh-tokoh seperti Rd. Machyar Anggakusumadinata, Mang Koko, Ujo Ngalagena, Nano Sutarno dan lain-lain membuat buku-buku pelajaran seni suara dalam bentuk kawih.

Kawih berkembang bukan pada bentuk anggana saja, melainkan mulai berkembang pula pada bentuk-bentuk lain, yaitu dengan bentuk-bentuk layeutan suara. Kawih mempunyai "sejak" yang tersendiri. Hal ini bisa kita perhatikan dari pergelarannya, iringannya, dan teknik bernyanyi termasuk di dalamnya uparengga-uparengga suara yang disajikan. Laras-laras pada kawih dalam lagu-lagu remaja kebanyakan berlaras pelog dan madenda. Sedangkan laras salendro terasa sangat jarang sekali.

\section{Kawih Barudak}

Kawih barudak merupakan sebuah jenis karawitan sekar yang substansinya adalah suara anak-anak. Kawih-kawih kawih barudak biasanya dinyanyikan oleh anak-anak dalam kehidupan sehari-hari mereka dan biasanya dibawakan ketika mereka sedang bermain dengan teman-teman sebaya. Pemaparan tentang kawih barudak ini juga diungkap oleh Sadkar dalam Soepandi 1985:15) bahwa: Kawih barudak artinya nyanyian anak-anak dan kawih adalah bahasa ikatan yang merupakan curahan rasa yang disajikan memerlukan lagu.

\section{Pembahasan}

Kawih oray bungka merupakan sebuah kawih barudak yang jika dilihat dari liriknya sangat sederhana. Isi dari syair kawih tersebut adalah sebagai berikut:

Oray bungka keur lapat taya hakaeun

Ulak-ilik pasemon pikagilaeun 
Mata na curinghak

Sungutna calawak nembongkeun gugusi

dek nyapluk nutipandeuri

oray bungka sedang lapar tidak ada makanan

lirik sana - lirik sini membuat jijik

matanya tajam

mulutnya menganga menunjukan gusi

akan memakan yang paling belakang

Sebenarnya jika kita tinjau dari segi lirik memang ada beberapa karya yang hampir menyerupai karya ini, diantaranya ada lagu kaulinan barudak yang berjudul oray-orayan dan dalam versi bahasa Indonesia yang berjudul ular naga panjang. Akan tetapi hal tersebut tidak mengurangi keoriginalitasan dari karya oray bungka itu sendiri. Mang Koko membuat lirik dan notasi yang berbeda dibandingkan kedua lagu tersebut. Tidak hanya itu, dalam karya ini juga secara tidak langsung menuntut para pemain yaitu peserta didik untuk saling bekerja sama dalam sebuah permainan dan sebuah pembelajaran, karena karya ini tidak hanya dinyanyikan saja melainkan sambil dipraktekan dengan gerakan khusus. Berikut hal-hal yang bisa diolah dalam karya ini sebagai berikut:

\section{Kebersamaan}

Dalam permainan oray bungka ini, anak dituntut untuk bekerja sama dan saling bahu membahu membentuk suatu barisan, satu sama lain saling memegang belakang baju atau pundak dari temannya yang ada di depan. Sedangkan temannnya yang paling depan memimpin pergerakan dari barisan yang membentk seolah-olah membentuk seekor ular yang panjang. 


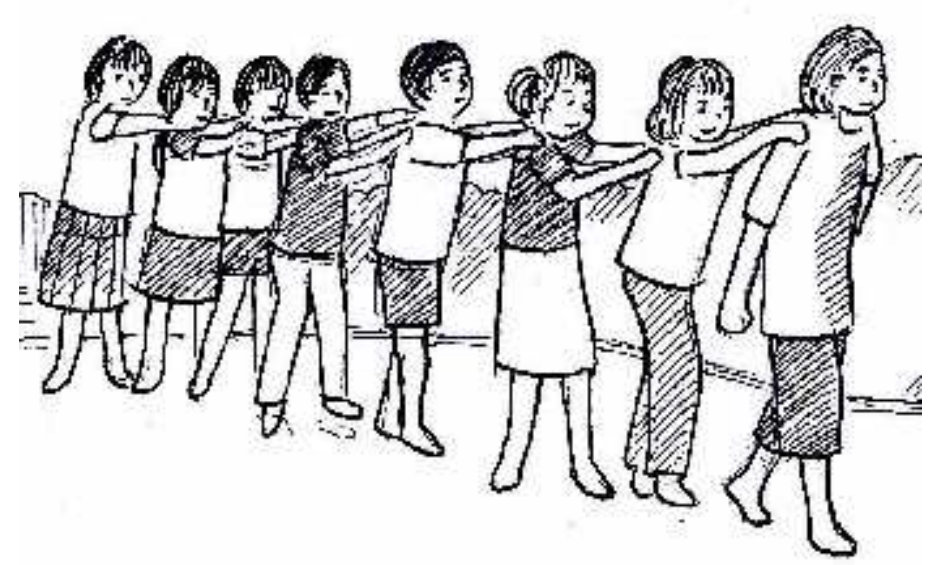

Gambar 1. Beberapa Orang Anak Berbaris dan Saling Memegang Pundak Teman Di depannya Sehingga Membentuk Barisan yang Panjang Seperti Ular

Sumber: Denden Setiaji, 2015

Pada bagian lain ada dua orang anak yang saling berhadapan dan saling memegang tangan kemudian mengankat tangan tersebut sehingga barisan anak-anak yang membentuk ular tersebut dapat memasuki kolong kedua tangan anak yang menjaga sambil menyanyikan lagu oray bungka dan pada akhir lagu yang syairnya "dek nyapluk tipandeuri" kedua anak yang menjaga harus menurunkan tangannya dan menangkap salah satu anak yang terlibat dalam barisan. Anak yang tertangkap mendapat giliran jaga begitu seterusnya hingga semua anak kebagian jaga.

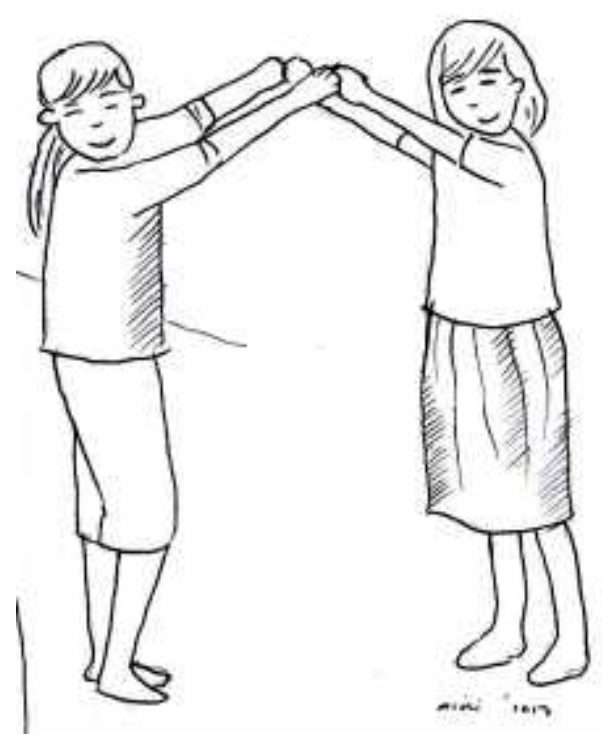

Gambar 2. Dua Orang Anak Saling Berpegangan Tangan dan Bertugas Sebagai Penjaga Sumber: Denden Setiaaji, 2015 


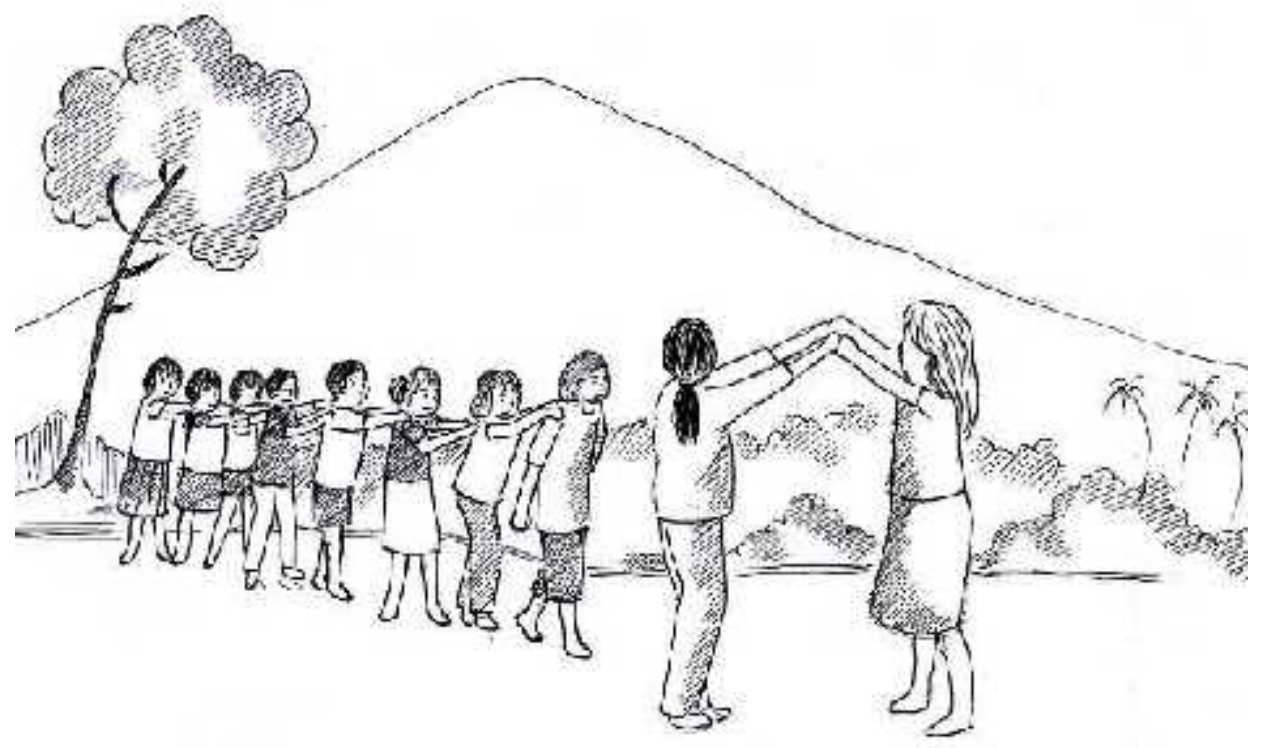

Gambar 3. Beberapa Orang Anak Berbaris dan Berjalan Menuju Dua Orang Anak yang Menjaga dan Bersiap Menangkap

Sumber: Denden Setiaji, 2015

\section{Kekompakan}

Kekompakan menjadi salah satu poin yang penting dalam memainkan karya ini, karena setiap anak harus hafal lagu dan birama disesuaikan dengan pergerakan kaki mereka sehingga jika hal tersebut diabaikan, maka penyajian karya ini akan sangat sulit terlaksana.

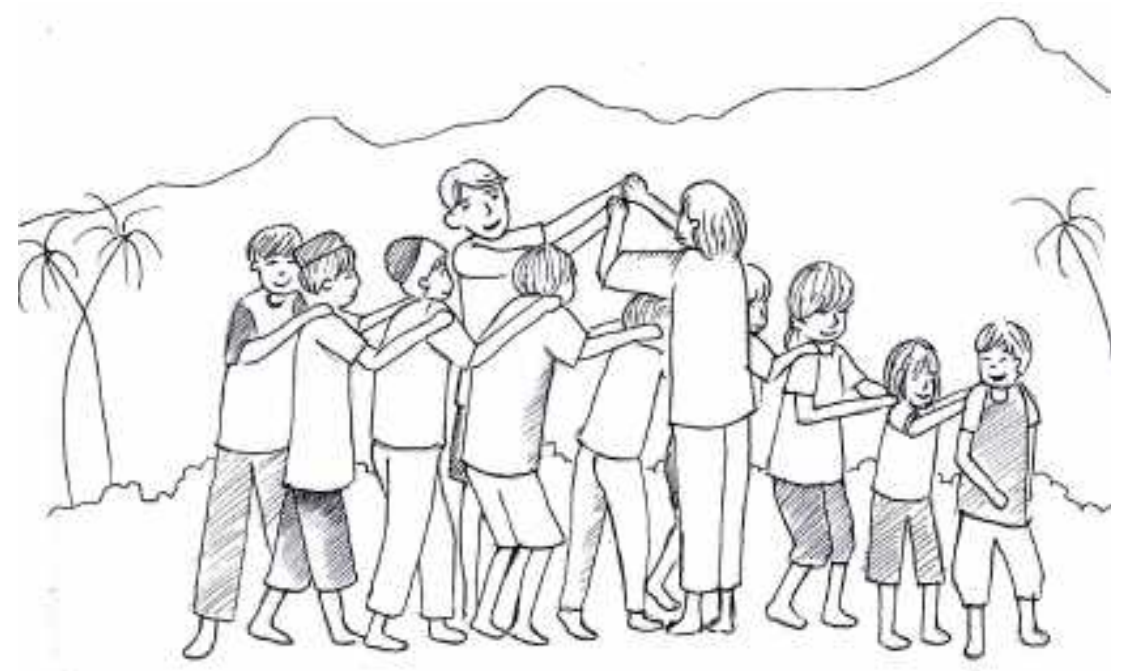

Gambar 4. Anak -Anak dengan Kompaknya Memasuki Lorong yang Dibuat Oleh Dua Orang Anak

Sumber: Denden Setiaji, 2015 


\section{Pengenalan Nada Salendro}

Lagu oray bungka ini diciptakan dengan menggunakan laras salendro dan menggunakan notasi-notasi yang bisa dikatakan tidak terlalu sulit untuk dihafalkan oleh anak-anak jenjang usia dini maupun sekolah dasar. Akan tetapi, pengenalan notasi sebaiknya tidak dipelajari terlebih dahulu melainkan yang harus dipelajari terlebih dahulu adalah kawih oray bungka itu sendiri setelah anak anak benar-benar memahami kawih tersebut, barulah pembelajaran dilanjutkan pada pembelajaran notasi dari lagu oray bungka.

\section{Pembelajaran Notasi Melalui Lagu}

Seperti pada pemaparan sebelumnya, karya ini secara tidak laangsung mengajarkan tentang notasi lagu salendro. Peserta didik dapat berperan aktif dalam dalam menyanyikan lagu oray bungka, baik dari lirik lagu maupun notasi dari lagu oray bungka tersebut. Berikut merupakan lirik dan notasi dari lagu oray bungka:

\section{Oray Bungka}

$$
\begin{aligned}
& \text { Sangifan: Mang Kokc Laras = Salenáro }
\end{aligned}
$$

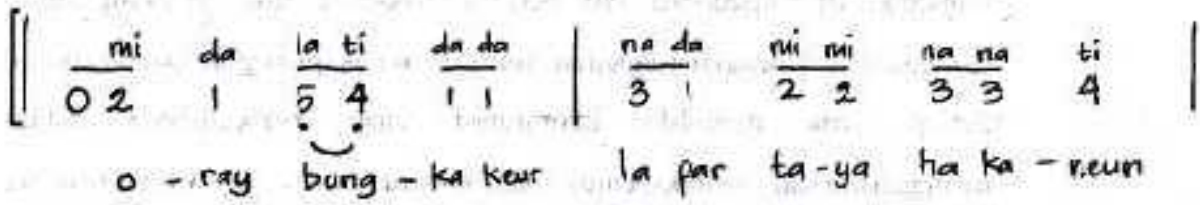

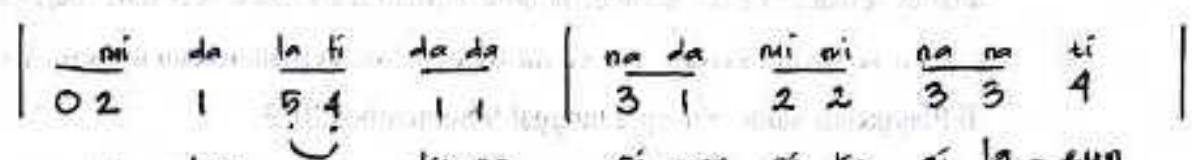

$$
\begin{aligned}
& \text { u. lak } \dot{i} \text { - líkpa si mor pi ka gi la-eun }
\end{aligned}
$$

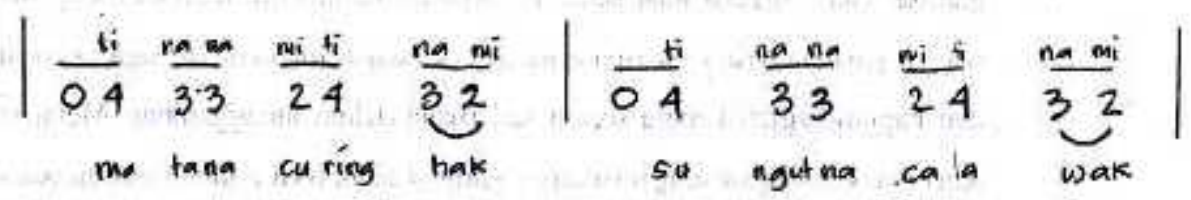

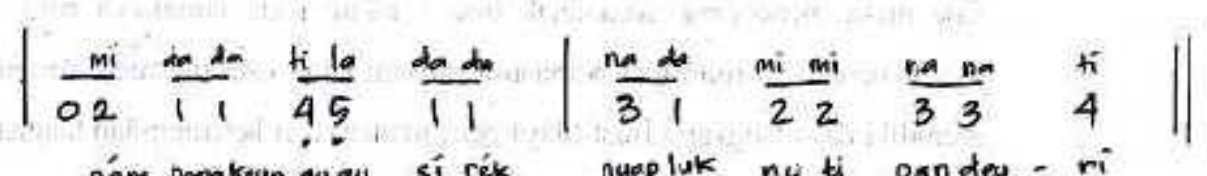

$$
\begin{aligned}
& \text { ném bongkeungugu sí rék nyapluk nu ti pandes - ri }
\end{aligned}
$$

Gambar 5. Lagu Oray Bungka Berikut Penulisan Notasi

Sumber: Denden Setiaji, 2015 


\section{Simpulan}

Kawih barudak berjudul oray bungka karya Mang Koko ini secara tidak langsung memberikan manfaat bagi anak-anak. Manfaat pembelajaran kawih barudak dalam lagu oray bungka ini diantaranya adalah melatih motorik, psikomotorik dan aspek apektif tentang permainan tersebut. Hal unik yang didapat melalui permainan ini adalah secara tidak disadari anak-anak mempelajari tangga nada salendro. Permainan ini memiliki dampak yang sangat positif bagi kehidupan anak-anak dimasa dewasa, karena nilai-nilai kearifan lokal yang terdapat dalam permainan ini, dapat menjadi pengalaman empiris ketika mereka dewasa. Pengalaman empiris ini merupakan salah satu cara pewarisan budaya kepada generasi berikutnya. 


\section{Daftar Pustaka}

Soepandi, A dan Umsari, OS. (1985). Kakawihan Barudak Nyanyian Anak-Anak Sunda. Bandung: Depdikbud Dirjen Kebudayaan Proyek Penelitian dan Pengkajian Kebudayaan Nusantara.

Wacik, J. (2011). 24 Karakter Modal Membangun Bangsa. Menteri Kebudayaan dan Pariwisata RI.

Warnika, E. (2010). Pangauban Sekar. Diunduh tanggal 15 oktober 2013. (Tersedia online) http://pangauban-sekar.blogspot.com/2010/05/karawitansekar.html 